\title{
Exploring the links between offshoring and innovation
}

\author{
Davide Castellani • Maria Luisa Mancusi • \\ Grazia D. Santangelo • Antonello Zanfei
}

Published online: 10 January 2015

(C) Associazione Amici di Economia e Politica Industriale 2015

Offshoring is broadly defined as a firm's allocation of business activities to another country, either by obtaining goods and services from an unaffiliated foreign company or by investing in a foreign affiliate or joint venture. ${ }^{1}$ Traditionally the offshoring phenomenon has involved manufacturing activities and more recently

\footnotetext{
${ }^{1}$ Resorting to foreign unaffiliated companies is often dubbed as offshore outsourcing, including pure supply relationships as well as more comprehensive partnership subcontracting. Offshoring within the boundaries of multinational enterprises (MNEs) is also referred to as offshore in-house sourcing (OECD 2006) or captive offshoring (Kedia and Mukherjee 2008). Strictly speaking, this definition implies a total or partial closure of activities at home and their transfer to new or existing foreign affiliates. However, it is widely accepted that offshoring may also include all greenfield and brownfield foreign direct investment (FDI) and outsourcing to independent companies, no matter whether they substitute for activities at home.
}

D. Castellani

Department of Economics, University of Perugia, Via Pascoli, 20, 06123 Perugia, Italy e-mail: davide.castellani@unipg.it

M. L. Mancusi

Department of Economics and Finance, Catholic University (Milan), L.go Gemelli 1, 20123 Milan, Italy

e-mail: marialuisa.mancusi@unicatt.it

G. D. Santangelo

Department of Political and Social Sciences, University of Catania, Via Vittorio Emanuele II, 8, 95131 Catania, Italy

e-mail: grsanta@unict.it

\section{A. Zanfei $(\square)$}

Department of Economics, Society and Politics, University of Urbino, Via Saffi 42, 61029 Urbino, Italy

e-mail: antonello.zanfei@uniurb.it 
administrative and technical services as well advanced services and R\&D-related functions (Lewin et al. 2009; Castelli and Castellani 2013; Albertoni and Elia 2014).

Different streams of literature have analyzed offshoring looking at both the determinants of firms' engagement in international production, and the effects of such activities in the home and host countries. It is relatively safe to say that empirical evidence on the determinants of offshoring is richer than studies on the effects. In this perspective, this Special Issue will fill a gap in the literature by focusing on the latter.

As for the effects of offshoring, and, more generally, of multinational activity in host countries, one has to distinguish direct effects from indirect effects. Direct effects refer to the fact that incoming MNEs tend to be relatively more productive than domestic firms, and to concentrate in sectors with higher average productivity. Indirect effects derive instead from the fact that offshored activities by MNEs may cause pecuniary and technological externalities, as well as crowding-out and business stealing effects. While direct effects usually positively contribute to aggregate productivity, indirect effects may act in the opposite direction (Barba Navaretti and Venables 2004; Castellani and Zanfei 2006; Piscitello and Santangelo 2007).

The empirical literature on the impact of incoming multinational activity on the host economy has provided convincing evidence of a positive direct effect on productivity and innovation. On the one hand, there are many studies showing that foreign-owned firms are both more productive and more innovative than domesticowned firms (e.g. Castellani and Zanfei 2006; Criscuolo and Martin 2009; Criscuolo et al. 2010; Bloom et al. 2012). On the other hand, studies show that domestic firms acquired by a foreign multinational tend to experience productivity gains and achieve higher innovation performance after the acquisition (Arnold and Javorcik 2009; Damijan et al. 2014; Guadalupe et al. 2012).

The indirect effect of MNEs in the host country has been investigated extensively in the empirical literature, however no clear consensus has been reached. The most common empirical approach links the productivity of domestic firms to a measure of MNEs activity in the same sector (and, possibly, geographic area). Despite a large number of studies (Görg and Greenaway 2004; Meyer and Sinani 2009; Iršová and Havránek 2013) at various levels of analysis, including the regional level (e.g. Haskel et al. 2007; Peri and Urban 2006; Girma and Wakelin 2007; Greenstone et al. 2010; Castellani and Pieri 2015), results are still inconclusive. Scholars have investigated under which conditions such indirect effects on productivity of local firms are more likely to be positive. A number of studies, discussed, inter alia, in Castellani and Zanfei (2006), Smeets (2008) and Gorodnichenko et al. (2014), point out the role of technology gaps, absorptive capacity, mode of entry, nationality of the MNE, input and output linkages. The phenomenon of linkage creation and interactions among firms, has been addressed specifically in many contributions, in order to identify the channels through which such spillovers take place (Jindra et al. 2009; Santangelo 2009; Godart and Görg 2013; Girma et al. 2014), the role of market competition in easing or inhibiting linkage creation and, hence local spillovers (Santangelo 2012; Perri et al. 2013), and the dynamics of cluster formation in the host economy that such linkages and spillovers may initiate (Mudambi and Santangelo 2014). More generally, there is an issue about the extent 
to which productivity is the best measure to capture technology and knowledge transfer from MNEs to local firms. As noted, for example, in Castellani (2012), framing the effects of MNEs in terms of productivity gains may confound knowledge spillovers with pecuniary externalities and market stealing effects. One way to deal with this issue, could be to use more direct measures of knowledge transfer from MNEs to local firms, such as patent citations, of competence upgrading of local firms, or direct measures of innovation. However, only few studies have pursued this line of investigation so far (Branstetter 2006; Veugelers and Cassiman 2004; Saliola and Zanfei 2009; Singh 2007).

The literature on the home effects of offshoring is more scattered. A number of studies has provided evidence that firms investing abroad tend to be more productive than domestic firms (Wagner 2011). These findings are consistent with the idea that economies with a larger share of highly productive firms (thus a higher average productivity) should also exhibit a larger share of firms investing abroad. Other studies have found that investing abroad may further reinforce the productivity of investing firms (e.g. Hijzen et al. 2011); while only a few works have addressed the indirect effects that firms investing abroad may have on their home country (e.g. Castellani and Zanfei 2006; Vahter and Masso 2007; Piscitello and Santangelo 2010).

With specific reference to $R \& D$ offshoring, the debate on its effects on the competitive advantage of investing firms is still ongoing. On the one hand, the literature on international knowledge sourcing argues that R\&D FDI increases asset seeking and knowledge creation in the long run (Cantwell 1995; Zanfei 2000; Le Bas and Sierra 2002; Narula and Zanfei 2005) and economic performance in the short run. R\&D offshoring enables investing firms to tap into the host country's expertise and capabilities, which contribute to enhance firm performance and knowledge creation at home by means of reverse knowledge transfer (RKT) from foreign subsidiaries to the parent company (Ambos et al. 2006; Griffith et al. 2006; Rabbiosi and Santangelo 2013). It remains that firm-level evidence on the relationship between R\&D offshoring and innovation is scant (Nieto and Rodríguez 2011). In addition, the analysis of the role of FDI for a firm's ability to take the technological leadership over its rivals on a worldwide scale has been limited. The few studies looking at technological leadership are affected by some crucial methodological problems, as they overlook the amount of $R \& D$ expenditures that firms can bear and the 'endogenous' thresholds they need to overcome in order to stay among the leaders (Cantwell and Andersen 1996; Alcácer and Chung 2007).

On the other hand, it has been highlighted that offshoring R\&D may 'hollow-out' knowledge from the offshoring firm and region (Kotabe 1990). The fear is that firms offshoring strategic activities will lose the capabilities offshored as new countries emerge with the basic capabilities needed to provide some technology-based services (Ghauri and Santangelo 2012; Lieberman 2004; Narula 2002). However, the evidence on negative effects of R\&D offshoring on the home country knowledge base is not conclusive, and several studies have provided support to the opposite view. Castellani and Pieri (2013) document positive effects of R\&D offshoring on the home region productivity growth. Piscitello and Santangelo (2010), D'Agostino and Santangelo (2012), and D'Agostino et al. (2013) document positive effects of 
R\&D offshoring in fast-growing emerging economies on knowledge creation in the home country and region.

To summarize, over the past couple of decades there has been an extensive and growing attention to the effects of offshoring on economic performance with some substantial incursions into the analysis of how international production affects innovation. While some of the latter consequences of offshoring can be captured by means of productivity dynamics associated to cross-border activities, when it comes to knowledge creation, transfer and accumulation, effects are more difficult to measure. Hence the evidence is weaker and it becomes harder to provide conclusive support to alternative views emerging in the literature.

This Special Issue on Offshoring and Innovation, which collects a selection of papers presented at the Final Conference of a project on "Production, R\&D and knowledge offshoring: economic analyses and implications for Italy" (prot. 2009KEKA5W), funded under the PRIN 2009 framework by the Italian Ministry of University and Research, aims to address some of the gaps discussed above through four articles investigating:

- the effects of production offshoring on innovative activities of manufacturing firms in the home country;

- the differential effects of R\&D FDI and FDI in other economic activities on the technological leadership of the offshoring MNEs;

- the effects of R\&D offshoring in emerging economies on the knowledge creation of the offshoring MNEs and home system of innovation;

- the effects of inward FDI on innovation capabilities in host locations.

Three articles in the special section focus on the home effects of R\&D offshoring adopting different levels of analysis.

Bernhard Dachs, Bernd Ebersberger, Steffen Kinkel and Oliver Som in their study "The Effects of Production Offshoring on R\&D and Innovation in the Home Country" investigate the effects of production offshoring on the innovation activities of manufacturing firms in the home country employing a dataset of more than 3,000 manufacturing firms from seven European countries. Their findings rule out the concerns that offshoring may hurt innovation because of the lost links between production and product development as offshoring firms on average are found to employ a higher share of $R \& D$ and design personnel, introduce new products more frequently to the market, and invest more frequently in advanced process technologies compared to non-offshoring firms.

Sandro Montresor and Antonio Vezzani in their study "On the R\&D giants' shoulders. Do FDI help to stand on them?" investigate the effects of R\&D offshoring in terms of technological leadership of the offshoring MNEs, that is their ability of being among the top R\&D world investors. In particular, by distinguishing FDI in R\&D from FDI in other economic activities this study shows that increasing the number of FDI projects in R\&D increases the chances that a firm enters the top R\&D circles of the European Industrial Research and Innovation Scoreboard. 
Similarly, the number of R\&D FDI projects reduces the probability of exiting from such circles, while that of non-R\&D projects does not.

The third study "The neglected effects of R\&D captive offshoring in emerging countries on the creation of knowledge at home" by Lorena D'Agostino develops a critical review of the current streams of literature about the effects of captive R\&D offshoring in emerging countries from advanced countries on the creation of knowledge at both the headquarter and the home system of innovation. Based on the literature on the knowledge-based view of the firm, the study critically reviews the recent empirical evidence in relation to two possible effects, i.e. the 'RKT-based division of labor' hypothesis and the 'hollowing-out' hypothesis. The study concludes that positive effects are likely to occur, but also that there is a need for further empirical evidence.

As far the effects on host locations are concerned, Roberto Antonietti, Raffaello Bronzini and Giulio Cainelli in their study "Inward greenfield FDI and innovation" investigate whether inward greenfield FDI is related to sectoral innovative activity in 103 Italian provinces (NUTS 3 level of Eurostat classification) by regressing the annual number of patents in each province and industry against a series of FDI variables. Their analysis suggests that larger inward FDI in services (and not in manufacturing) positively influences local patenting activity in knowledge-intensive business services.

\section{References}

Albertoni, F., \& Elia, S. (2014). The global sourcing of business services: Evidence from the offshoring research network survey. Economia e PoliticaIndustriale, 41(2), 131-146.

Alcácer, J., \& Chung, W. (2007). Location strategy and knowledge spillovers. Management Science, 53(5), 760-776.

Ambos, T. C., Ambos, B., \& Schlegelmilch, B. B. (2006). Learning from foreign subsidiaries: An empirical investigation of headquarters' benefit from reverse knowledge transfers. International Business Review, 15(3), 294-312.

Arnold, J., \& Javorcik, B. S. (2009). Gifted kids or pushy parents? Foreign direct investment and plant productivity in Indonesia. Journal of International Economics, 79(1), 42-53.

Barba Navaretti, G., \& Venables, A. (2004). Multinational firms in the world economy, Princeton University Press.

Bloom, N., Sadun, R., \& Van Reenen, J. (2012). Americans do IT better: US multinationals and the productivity miracle. American Economic Review, American Economic Association, 102(1), 167-201.

Branstetter, L. (2006). Is foreign direct investment a channel of knowledge spillovers? Evidence from Japan's FDI in the United States. Journal of International Economics, 68, 325-344.

Cantwell, J. (1995). The gobalisation of technology: what remains of the product cycle model? Cambridge Journal of Economics, 19, 155-174.

Cantwell, J. A., \& Andersen, H. B. (1996). A statistical analysis of corporate technological leadership historically. Economics of Innovation and New Technology, 4(3), 211-234.

Castellani, D. (2012). In praise of pecuniary externalities. The European Journal of Development Research, 24(1), 15-19.

Castellani, D., \& Pieri, F. (2013). R\&D offshoring and the productivity growth of European regions. Research Policy, 42(9), 1581-1594. doi:10.1016/j.respol.2013.05.009.

Castellani, D., \& Pieri, F. (2015). Outward investments and productivity. Evidence from European regions, Regional Studies, (forthcoming). 
Castellani, D., \& Zanfei, A. (2006). Multinational firms, innovation and productivity. Cheltenham: Edward Elgar.

Castelli, C., \& Castellani, D. (2013). The internationalisation of R\&D: Sectoral and geographic patterns of cross-border investments. Economia e PoliticaIndustriale-Journal of industrial and business economics, 1, 127-143 (2013). doi:10.3280/POLI2013-001006.

Criscuolo, C., Haskel, J. E., \& Slaughter, M. J. (2010). Global engagement and the innovation activities of firms. International Journal of Industrial Organization, 28(2), 191-202.

Criscuolo, C., \& Martin, R. (2009). Multinationals and US productivity leadership: Evidence from Great Britain. The Review of Economics and Statistics, 91(2), 263-281.

D’Agostino, L. M., Laursen, K., \& Santangelo, G. D. (2013). The impact of R\&D offshoring on the home knowledge production of OECD investing regions. Journal of Economic Geography, 13(1), $145-175$.

D’Agostino, L. M., \& Santangelo, G. D. (2012). Do overseas R\&D laboratories in emerging markets contribute to home knowledge creation? Management International Review, 52(2), 251-273.

Damijan, J., Kostevc, Č., \& Rojec, M. (2014). Growing lemons or cherries? Pre and post-acquisition performance of foreign-acquired firms in new EU Member States. The World Economy,. doi:10. $1111 /$ twec. 12176 .

Ghauri, P. N., \& Santangelo, G. D. (2012). Multinationals and the changing rules of competition. Management International Review, 52(2), 145-154.

Girma, S., Gong, Y., Görg, H., \& Lancheros, S. (2014). Estimating direct and indirect effects of foreign direct investment on firm productivity in the presence of interactions between firms. Journal of International Economics,. doi:10.1016/j.jinteco.2014.11.007.

Girma, S., \& Wakelin, K. (2007). Local productivity spillovers from foreign direct investment in the UK electronics industry. Regional Science and Urban Economics, 37, 399-412.

Godart, O. N., \& Görg, H. (2013). Suppliers of multinationals and the forced linkage effect: Evidence from firm level data. Journal of Economic Behavior and Organization, 94, 393-404.

Görg, H., \& Greenaway, D. (2004). Much ado about nothing? Do domestic firms really benefit from foreign direct investment? The World Bank Research Observer, 19(2), 171-197.

Gorodnichenko, Y., Svejnar, J., \& Terrell, K. (2014). When does FDI have positive spillovers? Evidence from 17 transition market economies. Journal of Comparative Economics, 42(4), 954-969. ISSN: 0147-5967. doi:10.1016/j.jce.2014.08.003.

Greenstone, M., Hornbeck, R., \& Moretti, E. (2010). Identifying agglomeration spillovers: Evidence from winners and losers from large plants openings. Journal of Political Economy, 118(3), 536-598.

Griffith, R., Harrison, R., \& Van Reenen, J. (2006). How special is the special relationship? Using the impact of US R\&D spillovers on UK firms as a test of technology sourcing. American Economic Review, 96(5), 1859-1875.

Guadalupe, M., Kuzmina, O., \& Thomas, C. (2012). Innovation and Foreign Ownership. American Economic Review, 102(7), 3594-3627.

Haskel, J., Pereira, S., \& Slaughter, M. (2007). Does inward foreign direct investment boost the productivity of domestic firms? Review of Economics and Statistics, 89(3), 482-496.

Hijzen, A., Jean, S., \& Mayer, T. (2011). The effects at home of initiating production abroad: Evidence from matched French firms. Review of World Economics, 147(3), 457-483.

Iršová, Z., \& Havránek, T. (2013). Determinants of horizontal spillovers from FDI: Evidence from a large meta-analysis. World Development, 42, 1-15.

Jindra, B., Giroud, A., \& Scott-Kennel, J. (2009). Subsidiary roles, vertical linkages and economic development: Lessons from transition economies. Journal of World Business, Elsevier, 44(2), $167-179$.

Kedia, B. L., \& Mukherjee, D. (2008). Understanding offshoring: A research framework based on disintegration, location and externalization advantages. Journal of World Business, 44(3), 250-261.

Kotabe, M. (1990). The relationship between offshore sourcing and innovativeness of US multinational firms: An empirical investigation. Journal of International Business Studies, 21(4), 623-638.

Le Bas, C., \& Sierra, C. (2002). Location versus country advantages in R\&D activities: Some further results on multinationals' location strategies. Research Policy, 31(4), 589-609.

Lewin, A. Y., Massini, S., \& Peeters, C. (2009). Why are companies offshoring innovation and quest; the emerging global race for talent. Journal of International Business Studies, 40(6), 901-925.

Lieberman, J. I. (2004). Offshore outsourcing and America's competitive edge: LOSInG out in the high technology R\&D and services sectors. White paper by office of senator, Washington DC. 
Meyer, K. E., \& Sinani, E. (2009). When and where does foreign direct investment generate positive spillovers? A meta-analysis. Journal of International Business Studies, 40(7), 1075-1094.

Mudambi, R., \& Santangelo, G. D. (2014). From shallow resource pools to emerging clusters: The Role of MNE subsidiaries in peripheral areas. Regional Studies. doi:10.1080/00343404.2014.985199.

Narula, R. (2002). Innovation systems and 'inertia' in R\&D location: Norwegian firms and the role of systemic lock-in. Research Policy, 31, 795-816.

Narula R., \& Zanfei, A. (2005). Globalisation of Innovation. In J., Fagerberg, D., Mowery, \& R.R., Nelson, (Eds.) Handbook of innovation (pp. 318-345), Oxford University Press (Castellani, Palmero, Zanfei 2013).

Nieto, M. J., \& Rodríguez, A. (2011). Offshoring of R\&D: Looking abroad to improve innovation performance. Journal of International Business Studies, 42(3), 345-361.

OECD (2006). Offshoring and employment. Trends and impact, OECD, Paris

Peri, G., \& Urban, D. (2006). Catching-Up to foreign technology? Evidence on the Veblen- Gerschenkron effect of foreign investment. Regional Science and Urban Economics, 36, 72-98.

Perri, A., Andersson, U., Nell, P. C., \& Santangelo, G. D. (2013). Balancing the trade-off between learning prospects and spillover risks: MNC subsidiaries' vertical linkage patterns in developed countries. Journal of World Business, 48(4), 503-514.

Piscitello, L., \& Santangelo, G. D. (2007) (Eds.) Do multinationals feed local development and growth? Amsterdam: Elsevier.

Piscitello, L., \& Santangelo, G. D. (2010). Does R\&D offshoring displace or strengthen knowledge production at home? Evidence from OECD countries. In: F. J., Contractor, V., Kumar, S. K., Kundu, T., Pedersen (Eds.). Global outsourcing and offshoring-an integrated approach to theory and corporate strategy. Cambridge: Cambridge University Press.

Rabbiosi, L., \& Santangelo, G. D. (2013). Parent company benefits from reverse knowledge transfer: The role of the liability of newness in MNEs. Journal of World Business, 48(1), 160-170.

Saliola, F., \& Zanfei, A. (2009). Multinational firms, global value chains and the organisation of knowledge transfer. Research Policy, 38(2009), 369-381.

Santangelo, G. D. (2009). MNCs and linkages creation: Evidence from a peripheral area. Journal of World Business, 44(2), 192-205.

Santangelo, G. D. (2012). The tension of information sharing: Effects on subsidiary embeddedness. International Business Review, 21(2), 180-195.

Singh, J. (2007). Asymmetry of knowledge spillovers between MNCs and host country firms. Journal of International Business Studies, 38(5), 764-786.

Smeets, R. (2008). Collecting the pieces of the FDI knowledge spillovers puzzle. The World Bank Research Observer, 23(2), 107-138.

Vahter, P., \& Masso J. (2007). Home versus host country effects of FDI: Searching for new evidence of productivity spillovers. Applied Economics Quarterly (formerly: Konjunkturpolitik), 53(2), 165-196.

Veugelers, R., \& Cassiman, B. (2004). Foreign subsidiaries as a channel of international technology diffusion: Some direct firm level evidence from Belgium. European Economic Review, 48(2), $455-476$.

Wagner, J. (2011). Offshoring and firm performance: Self-selection, effects on performance, or both? Review of World Economics, 147(2), 217-247.

Zanfei, A. (2000). Transnational firms and the changing organisation of innovative activities. Cambridge Journal of Economics, 24(5), 515-542. 